\title{
ON THE POSSIBILITY OF AUTOCHTHONOUS CHAGAS DISEASE IN RORAIMA, AMAZON REGION, BRAZIL, 2000-2001
}

\author{
José Francisco LUITGARDS-MOURA(1), José BORGES-PEREIRA(2), Jane COSTA(3), Patrícia Lago ZAUZA(2) \& Maria Goreti ROSA-FREITAS(1,4)
}

\begin{abstract}
SUMMARY
Chagas disease has been almost entirely eradicated from the arid zones in Central and Northeastern Brazil where rare or no autochthonous cases have been reported. However, in the last 10 years the disease has increasingly been registered in the Amazon Region. Aiming to investigate the possibility of the occurrence of autochthonous cycle of Chagas disease in Roraima, triatomine collections, vectorial susceptibility studies (this one to be shown elsewhere), parasitological and serological analyses were conducted in three agricultural settlement areas (Rorainópolis, Passarão Project and Ilha Community). Blood-donor candidates were also investigated. This is the first epidemiological survey on Chagas disease conducted in agricultural settlements in Roraima. Triatomine species found were Triatoma maculata, Rhodnius pictipes, Rhodnius robustus and Panstrongylus geniculatus. Trypanosoma cruzi detection analyses included xenodiagnosis, indirect immunofluorescence, indirect hemaglutination, ELISA and kinetoplast PCR amplification. Natural triatomine infection was not found in intestinal contents. Twenty-five adult settlers (1.4\% out of 1821 , all $>15$ year-old, 20 migrants) presented anti-T. cruzi antibodies. Two migrant settlers (from Minas Gerais and Maranhão) tested positive for more than two serological tests, besides either being positive for xenodiagnosis or PCR. Results show that Chagas disease is not endemic in the areas studied. However, all elements of the transmission cycle are present, demanding for an adequate and continuous vigilance.
\end{abstract}

KEYWORDS: Chagas disease; Agricultural Settlements; Amazon; Roraima; Brazil

\section{INTRODUCTION}

In the past years, Chagas disease, an endemic disease usually linked to the arid zones of Central, Western and Northeastern regions of Brazil, has been diagnosed in the Amazon (FUNASA, 2002). In the Amazon region, Chagas disease was firstly observed in Belém (Pará State) in four individuals belonging to the same family (SHAW et al., 1969). The occurrence of Trypanosoma cruzi-like infections in several mammals has showed the presence of circulating parasite in the Amazonian ecosystem, while the human infection was rare (SHAW et al., 1969). However, lately Chagas disease has been observed in Amazonian localities of Pará, Amapá, Acre, Rondônia and Maranhão States (COURA et al., 1994b, COURA et al., 1995b, FRAIHA NETO et al., 1995, VALENTE et al., 1998, VALENTE et al., 1999). Autochthonous Chagas disease cases have not been reported in the State of Roraima.

The State of Roraima, situated in the Northern Region of Brazil, has an area of $225,116 \mathrm{~km}^{2}$ (population of 324,397 inhabitants, IBGE, 2000) covered by typical Amazon forest and its variations (about $85 \%$ ) and natural and cultivated savannah fields (the $15 \%$ remaining vegetation, Ministério das Minas e Energia, 1975). The climate is tropical wet and dry with an average temperature of $27.8^{\circ} \mathrm{C}$ (10-year average) (NASA, 2000) with low intra-annual variability. Average yearly rainfall amounts to approximately $429 \mathrm{~mm}$ (4-year average) (NASA, 2000). A recent three-year time series study showed a wet season between April and September, and a dry season between October and March for Boa Vista (ROSA-FREITAS et al., 2003).

Roraima has been receiving a great amount of migrants from many other Brazilian states mainly from the Northeastern and Northern regions. The 1980 Census indicated that migrants constituted more than $80 \%$ of the Roraima population. These migrants were mainly from the Northeastern (48\%) and Northern regions (32\%) (FREITAS, 1996). Even though the total migration contribution from those regions decreased, it still amounts to $40 \%$ of the total Roraima population in 2000 (Census 2000, IBGE, 2000), with 27\% Northeastern and 13\% Northern region originated migrants. Beginning in the 1980's with the gold rush and continuing nowadays with the hope of a better future, free land for agriculture in one of the newest formed States in the Brazilian Amazon (the formation of the State of Roraima is dated of 1988) have been the leading motivation for immigration to Roraima. Migrating individuals are allocated in agricultural settlements, usually the core for the formation of new cities, in close proximity with sylvatic ecotopes where triatomines have been reported and may place a risk

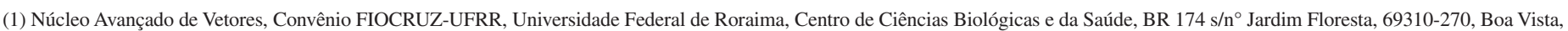
Roraima, RR, Brasil.

(2) Departamento de Medicina Tropical, Instituto Oswaldo Cruz, FIOCRUZ, Rio de Janeiro, RJ, Brasil.

(3) Coleção Entomológica, Instituto Oswaldo Cruz, FIOCRUZ, Rio de Janeiro, RJ, Brasil.

(4) Laboratório de Transmissão de Hematozoários, Departamento de Entomologia, Instituto Oswaldo Cruz, FIOCRUZ, Rio de Janeiro, RJ, Brasil.

Correspondence to: Dra. Maria Goreti Rosa-Freitas, Ploutarhou 17, Spata-Attikis 19004, Greece, e-mail: ptsour@tee.gr 


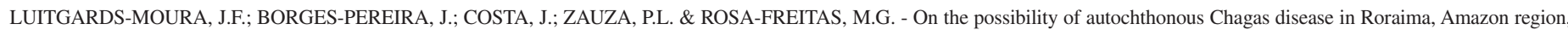
Brazil, 2000-2001. Rev. Inst. Med. trop. S. Paulo, 47(1):45-54, 2005.

for the establishment of autochtonous $T$. cruzi cycle transmission in the forests and savannahs of Roraima. To date, 34 agricultural settlements have been organized by the Institute for Agrarian Reform (INCRA - Instituto Nacional de Colonização e Reforma Agrária), all located in forested areas (except for one settlement). The agricultural settlements selected for this study were chosen due to their population size (Rorainópolis is the biggest Roraima settlement) and proximity with the capital Boa Vista (Passarão and Ilha are $50 \mathrm{~km}$ away from Boa Vista). Together the three settlements have a total of 1821 individuals, many of them migrants (Table 1). The capital Boa Vista is the city with the highest population in the state (200 thousand inhabitants, IBGE 2000). Some of the houses in the Boa Vista periphery, the poorest zones in the city, may be suitable for triatomine colonization due to poor brick and wood construction.

Table 1

Number of Roraima born and migrant settlers in three agricultural settlements

\begin{tabular}{lcccccc}
\hline Settlement & \multicolumn{2}{c}{$\begin{array}{c}\text { Born in } \\
\text { Roraima (\%) }\end{array}$} & \multicolumn{2}{c}{ Migrant (\%) } & \multicolumn{2}{c}{$\begin{array}{c}\text { Total of } \\
\text { settlers }(\%)\end{array}$} \\
\hline Rorainópolis & 427 & $(26.9)$ & 1161 & $(73.1)$ & 1588 & $(87.2)$ \\
Passarão & 74 & $(49.3)$ & 76 & $(50.7)$ & 150 & $(8.2)$ \\
Ilha & 81 & $(97.6)$ & 2 & $(2.4)$ & 83 & $(4.6)$ \\
\hline Total & 582 & $(31.9)$ & 1239 & $(68)$ & 1821 & $(100)$ \\
\hline
\end{tabular}

The agricultural settlement of Rorainópolis is now the municipality of Rorainópolis (State Law 100 of October 17, 1995 from an area formerly belonging to the municipality of São Luiz do Anauá). It was initiated in 1979 as the "INCRA village", i.e., created as a settlement project of the Institute for Agrarian Reform. Rorainópolis is located $291 \mathrm{~km}$ south from the capital Boa Vista (Fig. 1) occupying an area of $33,745 \mathrm{~km}^{2}$ (15\% of the total Roraima area) and a population of 17477 inhabitants $(5.4 \%$ of the total State, 2577 of which living in the city of Rorainópolis where the city hall is located, IBGE 2000) being the
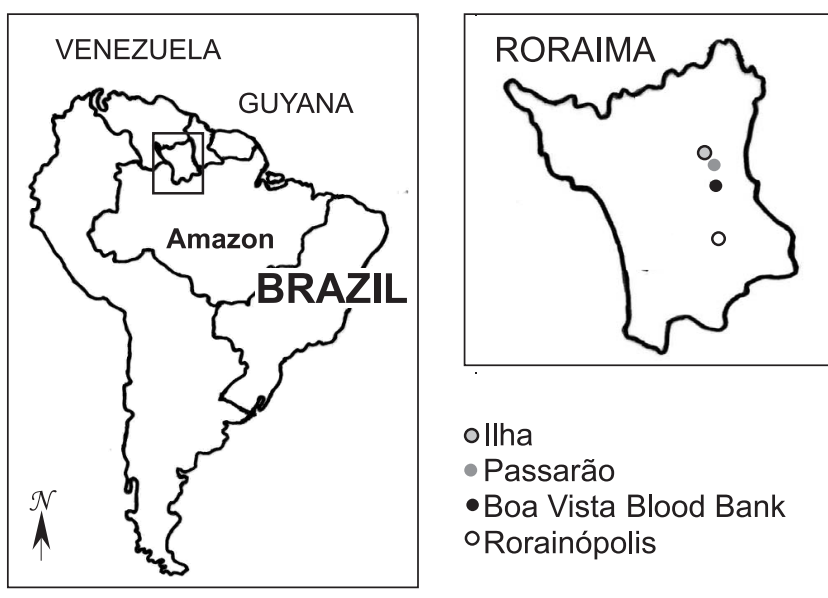

ollha

- Passarão

- Boa Vista Blood Bank

oRorainópolis biggest Roraima agricultural settlement. Most houses in the municipality are made of mud (taipa), whereas wooden constructions dominate the urban area (Fig. 2). There were no asphalted roads in Rorainópolis.

The Passarão community is an agricultural settlement initiated in 1991 situated $55 \mathrm{~km}$ north of Boa Vista, with a total population of 252 individuals. The community is located at the right edge of the Uraricoera River (Fig. 1). Three types of vegetation characterize the area - savannah, marginal river vegetation and seasonally flooded lands. Most of the area covered by savannah is used for pasture, soy and rice cultivation. The 48 houses of Passarão are mostly wooden made (Fig. 2).

The Ilha community is located next to Passarão, separated only by the Uraricoera River (Fig. 1). The community constituted by 117 individuals is formed in its almost totality by native Roraima people from diverse aboriginal communities, with predominance of the Camará and Napoleão native groupings (or malocas). All the population had been residing in the area for five five years (at 2000) practicing subsistence agriculture and fishing. There is no electricity and almost all house roofs are covered with dried leaves of the palm tree Attalea maripa (buriti) (Fig. 2).

The expansion of the urban population brings the risk of transfusional Chagas disease (DIAS et al., 2002). The Roraima blood bank (Hemocentro de Roraima) that centralizes blood collection, examination and distribution of blood bags for all State hospitals is located in Boa Vista $\left(00^{\circ} 56^{\prime} 35^{\prime \prime} \mathrm{N}\right.$ and $60^{\circ} 25^{\prime} 23^{\prime \prime} \mathrm{W}$, Fig. 1). From August 1987 this blood bank started to carry out routine serological assays for many diseases including Chagas disease.

This is the first epidemiological study on Chagas disease conducted in agricultural settlements in Roraima. Before, the National Serological Inquiry-NSI of 1978-1982 reported the findings of positive sera from 500 Boa Vista and Caracaraí domiciles (Public Health Governmental Program, Fundação Nacional de Saúde - FUNASA, CAMARGO et al., 1984).

This study aims to investigate the possibility of autochthonous Chagas disease in Roraima. Triatomine collections, serological and parasitological assays were conducted in three agricultural settlement areas. Blood donor candidates were also evaluated.

\section{MATERIALS AND METHODS}

1. Population and areas: The population studied included individuals originating from three Roraima agricultural settlements: the communities of Rorainópolis ( $00^{\circ} 56^{\prime} \mathrm{N}$ and $\left.60^{\circ} 25^{\prime} \mathrm{W}\right)$, Passarão $\left(03^{\circ} 05^{\prime}-03^{\circ} 20^{\prime} \mathrm{N}\right.$ and $\left.60^{\circ} 35^{\prime}-60^{\circ} 43^{\prime} \mathrm{W}\right)$ and Ilha $\left(03^{\circ} 05^{\prime}-03^{\circ} 20^{\prime} \mathrm{N}\right.$ and $60^{\circ} 35^{\prime}-60^{\circ} 43^{\prime} \mathrm{W}$ ) (Fig. 1). Age, origin and sex were annotated. Another group was constituted by Roraima born individuals, blood-donor candidates from the state blood bank (Hemocentro de Roraima, $00^{\circ} 56^{\prime} 35^{\prime \prime} \mathrm{N}$ and $\left.60^{\circ} 25^{\prime} 23^{\prime \prime} \mathrm{W}\right)$. These settlements were chosen due to their population size (Rorainópolis) and proximity with the capital Boa Vista (Passarão and Ilha). Settlers spontaneously signed a consent form to participate in this investigation. Methodology for triatomine and blood collection and, xenodiagnosis was previously assessed by the FIOCRUZ Ethical Commission. Results were shared with the participating individuals.

Fig. 1 - Brazil, Roraima, agricultural settlements and Boa Vista. 

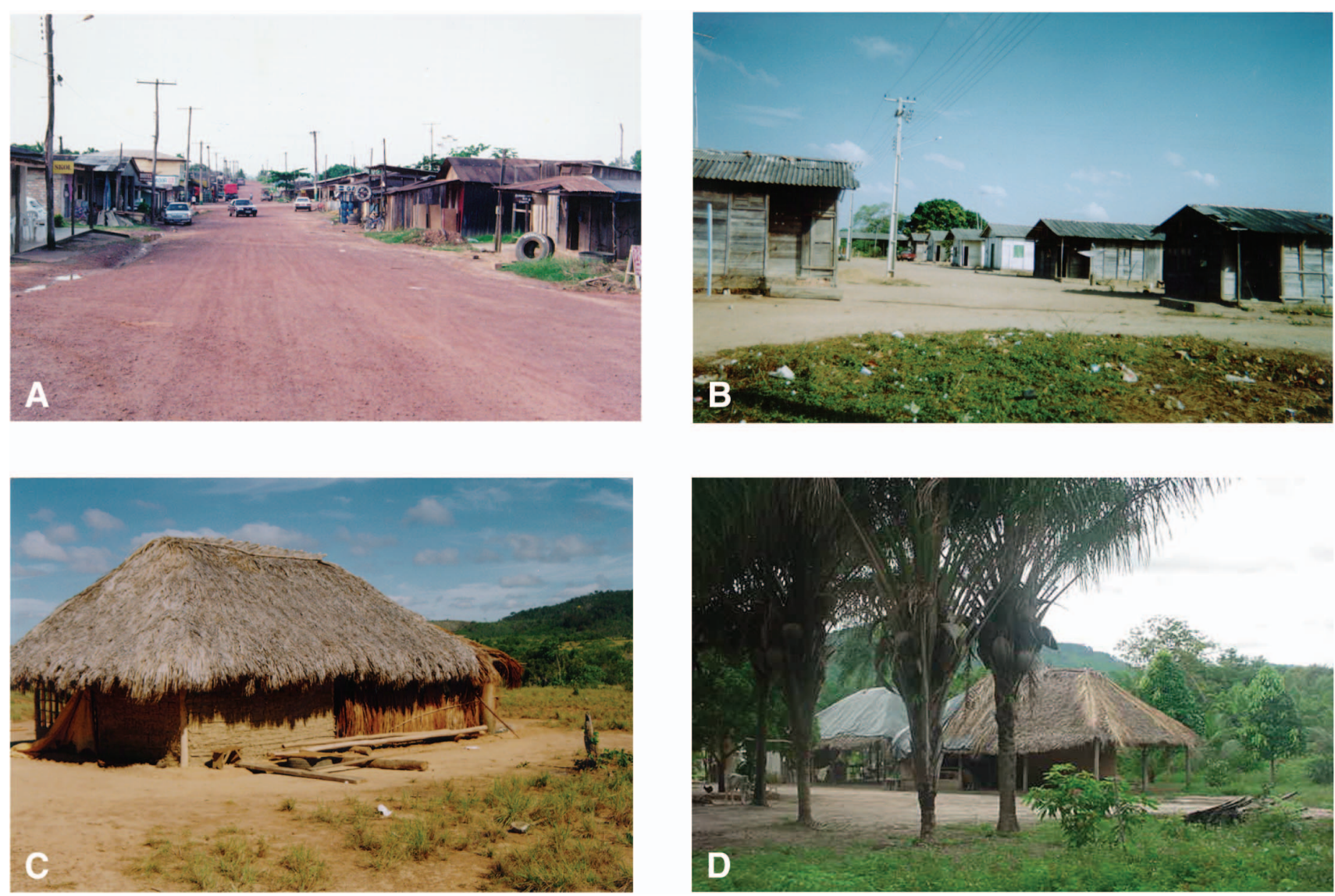

Fig. 2 - House constructions in Rorainópolis (A), Passarão (B) and Ilha (C). Buriti palm-trees Attalea maripa in the peridomicile, Ilha (D)

2. Triatomine collection: Collections were performed manually using a torch and tweezers in the domicile, the peridomicile (up to 50 $\mathrm{m}$ from the houses) and extradomicile (more than $50 \mathrm{~m}$ from the houses).

In the domiciles searches were done anti-clockwise in the internal and external wall surfaces, furniture and any other object that could shelter the vector, in all rooms.

In the peridomicile dog, pig, horse, cow and chicken lodging annexes were searched as well as food storages, fences and dry walls. Peridomiciliary trees were cut down. Trees and rocks located within $50 \mathrm{~m}$ of the house perimeter were exhaustively searched. All content of nests found in those sites were placed on top of a white cloth $(150 \mathrm{x}$ $150 \mathrm{~cm}$ ) for examination.

Light traps Baby BL-12 (Blue Light with UV lamp) were installed in the peri- and extradomicile between 19:00 and 22:00h.

Triatomines collected were placed in glass jars containing filter paper, closed with a piece of cloth and transported to the laboratory for identification using taxonomic keys (LENT \& WYGODZINSKY, 1979). After identification, triatomine intestinal contents diluted with saline were observed microscopically for flagelates detection. Salivary glands were not investigated.
3. Anti-T. cruzi antibodies screening in agricultural settlers: Serological screening started in December 2000 by the fingertip blood collection on filter paper carried out in 1821 individuals (1588 originating from Rorainópolis, 150 from Passarão and 83 from Ilha). Sample collection finished by January 2001. Serology was performed by indirect imunofluorescence (Kit IIF-Chagas, Bio-Manguinhos/ FIOCRUZ, as previously described by SOUZA \& CAMARGO, 1966).

4. Anti-T. cruzi antibodies screening in blood donor candidates: With the aim to identify Chagas disease cases in the Roraima born population, 68 Roraima-born individuals with positive serology in screening tests performed during the period January 1997-February 2001 in the Roraima Hemocentro were included in the study. Sixtythree individuals had been tested positive by ELISA (Abbott) and five by indirect hemaglutination - IHA (Biolab).

5. Serology confirmation: A total of 106 sera from 75 individuals (only 25 with positive TIFI in the blood eluate) from the agricultural settlements and 31 (29 positive by ELISA and two by IHA) from the Hemocentro underwent serological confirmation. Serological confirmation was performed by indirect imunofluorescence (Kit IIFChagas, Bio-Manguinhos/ FIOCRUZ), indirect hemaglutination-IHA (Kit Hemacruzi, Biolab, with 2-mercaptoethanol) and ELISA (Kits EIE- Bio-Manguinhos and EIE-recombinant CRA + FRA - Chagas Bio-Manguinhos). Non-heparinized $10 \mathrm{ml}$ venous blood samples were 


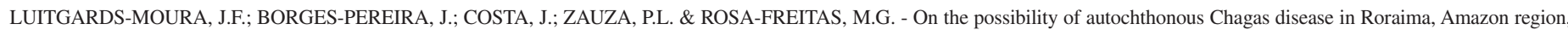
Brazil, 2000-2001. Rev. Inst. Med. trop. S. Paulo, 47(1):45-54, 2005.

obtained. Serum was separated, kept at $-20{ }^{\circ} \mathrm{C}$ and transported to the Laboratory of Parasitic Diseases (Department of Tropical Medicine, IOC, FIOCRUZ, Rio de Janeiro). Sera dilutions were 1:40 for IIF and IHA, 1:100 for ELISA, whereas $50 \mu$ of non-diluted serum were used for the recombinant ELISA as recommended by the manufacturers. Elisa cut-off values were 0.260 for ELISA and 0.202 for the recombinant ELISA. Sera was considered positive when presented 1:40 titles (BORGES-PEREIRA, 1997; ZAUZA, 2000). As recommended by PAHO/WHO (PAHO, 1976), a positive serum reacted in at least two different assays. A serum was inconclusive if positive for only one technique (CARVALHO, 1992).

6. Xenodiagnosis: Indirect xenodiagnosis was carried out in 56 seropositive individuals, 31 originated from the Roraima blood bank. For those 31 , xenodiagnosis was performed using $404^{\text {th }}$-instar nymphs of Triatoma infestans and Rhodnius prolixus. For the other 25 settlers blood samples, $404^{\text {th }}$-instar nymphs of $T$. infestans were used. Heparinized venous blood $(10 \mathrm{ml})$ were collected and placed in a masculine latex condom without lubricant and offered to triatomines placed in a cardboard box at room temperature, allowing them to feed for $2 \mathrm{~h}$. Forty-five days later, the stomach and/ or intestinal content of the insects were examined for flagelate detection.

7. PCR: The group of individuals submitted to xenodiagnosis was simultaneously evaluated by PCR. Blood samples $(10 \mathrm{ml})$ were collected without heparin and immediately mixed to $10 \mathrm{ml}$ of a lysis solution (6M guanidine-HCl, 0.2M EDTA, pH 8.0, ÁVILA et al., 1990). Samples were stored for one week at room temperature, boiled at $100{ }^{\circ} \mathrm{C}$ for 15 min to cleave kinetoplast DNA-kDNA and kept at $4{ }^{\circ} \mathrm{C}$ until DNA extraction (BRITTO et al., 1995). Blood mixture $(200 \mu \mathrm{l})$ was submitted to phenol: chloroform extraction followed by DNA precipitation with sodium acetate and ethanol (WINCKER et al., 1994). PCR amplification targeting of kDNA minicircles used primers as described in WINCKER et al. (1994). Hot-start PCR used $50 \mu \mathrm{l}(5 \mu \mathrm{l}$ of $100 \mathrm{mM}$ Tris- $\mathrm{HCl} \mathrm{pH} 8.3500 \mathrm{mM} \mathrm{KCl}, 4 \mu \mathrm{l}$ of $200 \mu \mathrm{M}$ dNTP mixture, $8 \mu \mathrm{l} 25 \mathrm{mM} \mathrm{MgCl}, 120 \mathrm{pmol}$ of each primer, 2.5 units of Taq polymerase and $5 \mu \mathrm{l}$ sample DNA). The PCR conditions were one cycle at $94{ }^{\circ} \mathrm{C}$ for one min, two cycles at $98{ }^{\circ} \mathrm{C}-1$ ', $64{ }^{\circ} \mathrm{C}-1$ ', 33 cycles at $94{ }^{\circ} \mathrm{C}-1$ ', $64{ }^{\circ} \mathrm{C}-1$ ', final extension at $72{ }^{\circ} \mathrm{C}$ for $10 \mathrm{~min}$ (DNA Thermal Cycler 9600-Applied Biosystems). Controls used human $\beta$-globin primers (SAIKI et al., 1985). The amplified products were submitted to a $2 \%$ agarose gel electrophoresis and visualized under UV light after ethidium bromide staining. T. cruzi group typing was not performed.

An individual was considered positive for T. cruzi if serologically positive for two tests or, for one serology test with positive parasitology tests (either xenodiagnosis or PCR).

\section{RESULTS}

1. Population and areas: A total of 1821 settlers and 68 blood donor candidates participated in the investigation. Settlers were constituted by 1588 individuals living in the urban areas of Rorainópolis, 150 of Passarão and 83 of Ilha (being 57.6\%, 59.5\% and $70.9 \%$ of the total population of each settlement, respectively). The 1588 individuals from Rorainópolis are mainly individuals resident in the urban area (the city of Rorainópolis), due to operational difficulties to reach the rural population. Blood donor candidates tested as seropositive for Chagas disease in blood donor screening performed previously at the Roraima blood bank constituted the group of 68 Roraima-born individuals. The term origin applies to place of birth. In relation to origin, Rorainópolis has the highest contribution of migrants, i.e., of individuals not born in Roraima. In Passarão, the ratio for migrants and Roraima born individuals are similar, while in Ilha, Roraima born individuals are in higher numbers (Table 1). The overall mean age of individuals was $25.2 \pm 17.6$ years $(24.9 \pm 17.3$ for Rorainópolis, $30.3 \pm 18.5$ for Passarão and $20.8 \pm 19.5$ for Ilha). From the total, $66 \%$ were below 30 years. No significant differences were found between sex ratios. Individuals originating from Maranhão, Pará and Amazon States, in this order, migrated in higher frequencies to Roraima (Table 2).

Table 2

Origin of settlers in three agricultural settlements in Roraima

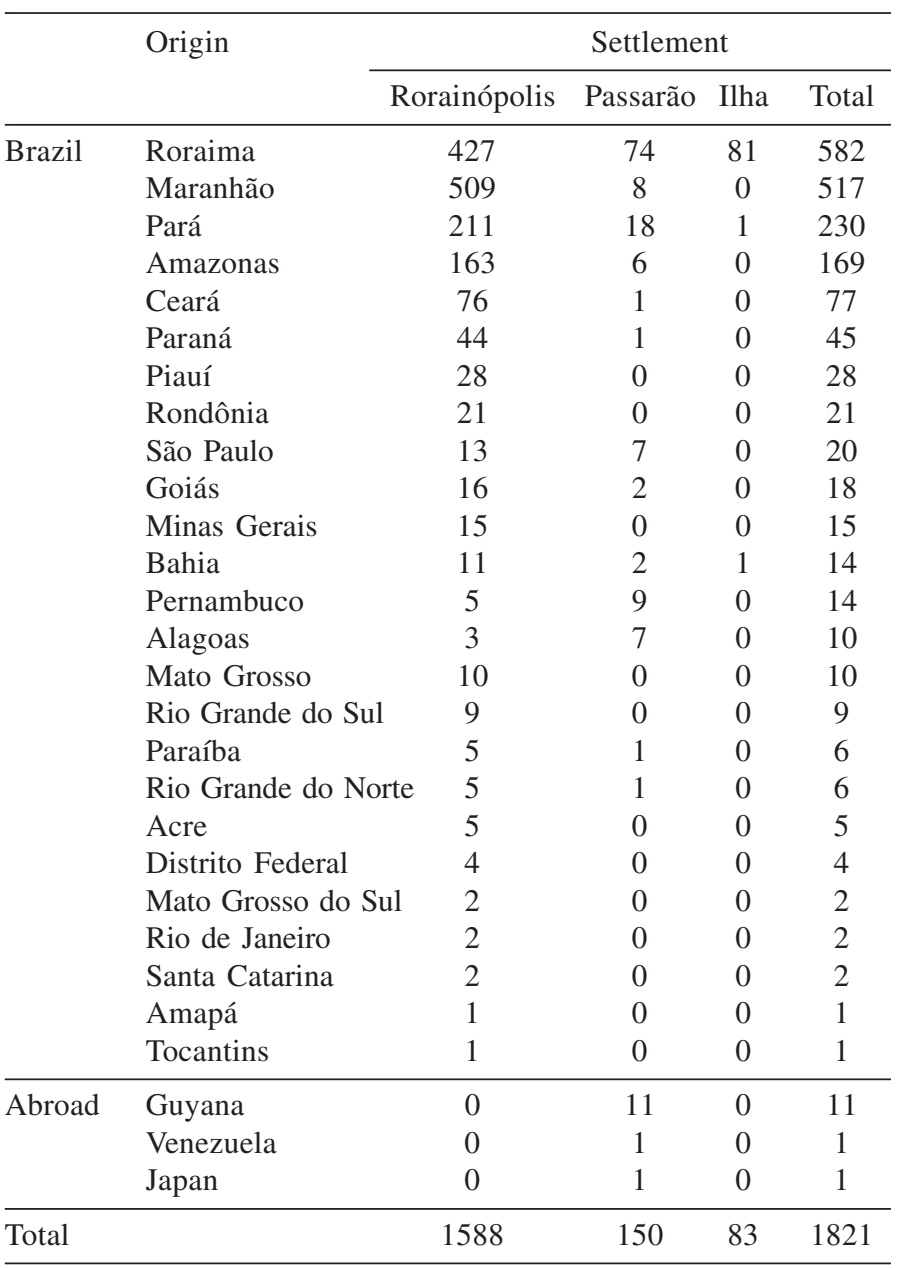

From the group of 68 blood donor candidates with a previous positive serology ( 62 by ELISA and 6 by IHA), all born and living in Roraima, 61 were males and seven were females with ages from 18 to 60 years old.

2. Triatomine collection: Four triatomine species were found, Triatoma maculata (383 specimens), Rhodnius pictipes (161), Rhodnius 
robustus (21) and Panstrongylus geniculatus (5) in collections performed through January 1999-February 2001 (Table 3).

A total of 450 collections were conducted in Rorainópolis including domicile and peridomicile annexes. No triatomines or their traces (ecdises or faeces) were found in domiciles and annexes. Domicile walls were made of mud (267 houses), wood (147) and brick (36). Collections in the buriti palm tree Attalea maripa, sometimes present in high density, in the peri- and the extradomicile were positive. In the peridomicile 26 palm-trees (out of 45 investigated) sheltered 135 specimens of $R$. pictipes ( 21 adults and 114 nymphs) and nine specimens of $R$. robustus (two adults and seven nymphs). This corresponds to a peridomiciliary infestation index of 57.8 (number of trees with triatomines/ number of trees $x$ 100) and 5.5 bugs/ infested tree. In the extradomicile 16 palm trees (out of 30 investigated) had 26 triatomine specimens belonging to $R$. pictipes (seven adults and 19 nymphs) and $12 R$. robustus (three adults and nine nymphs), an extradomiciliary infestation index of 53.3 with 2.4 bugs/ infested tree. The number of specimens for each species found per palm tree was not done. No triatomines were collected in the light traps during $40 \mathrm{~h}$ of collection (20 $\mathrm{h}$ peridomicile, $20 \mathrm{~h}$ extradomicile).

Passarão domiciliary collections in 48 houses (the totality of existing house, being 15 of mud, 28 of wood, five of brick) yield eight adults T. maculata found in two domiciles (one mud, one brick), a domiciliary infestation index of 4.2 (number of houses with triatomines/ number of houses $x$ 100). In the brick-wall house, three specimens were founded in a sofa while in the mud-wall house specimens were lodged in the wall. Inhabitants found another five adults $P$. geniculatus inside two houses during the dry season of the year 2000 (SeptemberMarch). In 48 peridomiciliary annexes, 383 specimens of triatomines were collected in eight annexes belonging to the species $T$. maculata (86 adults and 289 nymphs) and $P$. geniculatus (five adults), a peridomiciliary infestation index of 16.7 (number of annexes with triatomines/ number of annexes x 100). It is worth noting however, that 375 specimens (out of 383) were found in the chicken annexes of only three houses, i.e., 125 triatomines per chicken house. In the chicken houses, triatomines were found in the chicken nests, underneath cardboard boxes, wood pieces, stones and bricks. In the extradomicile six nests of the bird Egreta thula (garça, Ciconiiformes: Ardeidae), located at the right margin of the Uraricoera River, approximately seven $\mathrm{km}$ away from Passarão were negative.

Ilha collections were negative for the 17 domiciles investigated (the totality of existing house, being all wooden). There were neither chicken house annexes nor palm trees in this area.

No triatomine specimen was found naturally infected by tripanosomatids. There were dissected 227 T. maculata specimens (52 adults, 175 nymphs) from Passarão. From Rorainópolis 135 R. pictipes specimens (18 adults, 117 nymphs) and $14 R$. robustus specimens (4 adults, 10 nymphs) were examined.

3. Anti-T. cruzi antibodies screening in agricultural settlers: An initial screening was performed by IIF. Positive reactions were found in 25 settlers (1.4\% out of 1821), 21 from Rorainópolis, two

Table 3

Triatomine species found in three agricultural settlements in Roraima, in collections performed through January 1999-February 2001

\begin{tabular}{|c|c|c|c|c|c|c|c|c|}
\hline Settlement & Environment & Triatomine species & $\begin{array}{c}\mathrm{Nb} \text { of } \\
\text { collections }\end{array}$ & $\begin{array}{l}\text { Positive } \\
\text { collections }\end{array}$ & Adults & Nymphs & Total & $\begin{array}{c}\text { Infestation } \\
\text { index }^{2}\end{array}$ \\
\hline \multirow{9}{*}{ Rorainópolis } & \multirow{2}{*}{ Intradomicile } & Rhodnius pictipes & 450 & 0 & 0 & 0 & 0 & \multirow[t]{2}{*}{0} \\
\hline & & Rhodnius robustus & 450 & 0 & 0 & 0 & 0 & \\
\hline & Peridomicile (animal annexes) & Rhodnius pictipes & 450 & 0 & 0 & 0 & 0 & 0 \\
\hline & \multirow{2}{*}{ Peridomicile $\left(\right.$ palm trees $\left.{ }^{1}\right)$} & Rhodnius pictipes & 45 & 26 & 21 & 114 & 135 & \multirow{2}{*}{$57.8^{2}$} \\
\hline & & Rhodnius robustus & 45 & 26 & 2 & 7 & 9 & \\
\hline & \multirow[t]{2}{*}{ Extradomicile (palm trees) } & Rhodnius pictipes & 30 & 16 & 7 & 19 & 26 & \multirow{2}{*}{$53.3^{2}$} \\
\hline & & Rhodnius robustus & 30 & 16 & 3 & 9 & 12 & \\
\hline & \multirow[t]{2}{*}{ Subtotal } & Rhodnius pictipes & \multirow{2}{*}{525} & 26 & 28 & 133 & \multirow{2}{*}{$\begin{array}{c}161 \\
21\end{array}$} & \\
\hline & & Rhodnius robustus & & 16 & 5 & 16 & & \\
\hline \multirow[t]{6}{*}{ Passarão } & \multirow[t]{2}{*}{ Intradomicile } & Triatoma maculata & 48 & 2 & 8 & 0 & 8 & $4.2^{2}$ \\
\hline & & Panstrongylus geniculatus ${ }^{4}$ & 1 & 1 & 5 & 0 & 5 & -4 \\
\hline & Peridomicile & Triatoma maculata & 48 & 2 & 86 & 289 & 383 & $4.2^{2}$ \\
\hline & Extradomicile (bird nests ${ }^{3}$ ) & - & 6 & 0 & 0 & 0 & 0 & 0 \\
\hline & \multirow[t]{2}{*}{ Subtotal } & Triatoma maculata & \multirow{2}{*}{54} & 5 & 94 & 289 & \multirow{2}{*}{$\begin{array}{c}383 \\
5\end{array}$} & \\
\hline & & Panstrongylus geniculatus ${ }^{4}$ & & 1 & 5 & $\mathbf{0}$ & & \\
\hline Ilha & Intradomicile & - & 17 & 0 & $\mathbf{0}$ & $\mathbf{0}$ & $\mathbf{0}$ & 0 \\
\hline \multicolumn{2}{|l|}{ TOTAL } & 4 & 596 & 48 & 132 & 438 & $\mathbf{5 7 0}$ & \\
\hline
\end{tabular}

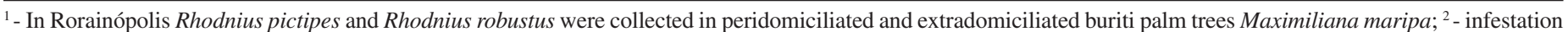

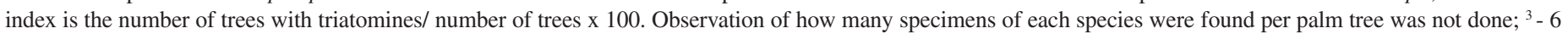

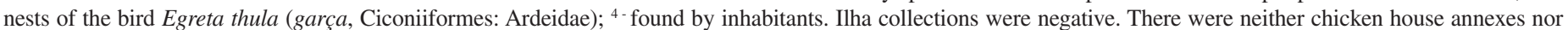
palm-trees in the peridomicile. 


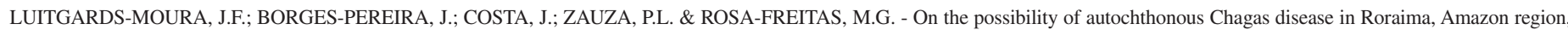
Brazil, 2000-2001. Rev. Inst. Med. trop. S. Paulo, 47(1):45-54, 2005.

from Passarão and two from Ilha (Table 4). Twenty IIF positive individuals were migrants (10 males and 10 females) and five were born in Roraima (three males and two females), ranging from 10 to 69 years (Fig. 3) that were then submitted to further confirmatory assays.

4. Anti-T. cruzi antibodies screening in blood donor candidates - Sixty-three individuals were positive by ELISA (Abbott) and five by indirect hemaglutination - IHA (Biolab).

5. Serology confirmation: The 12 settlers with $>2$ positive assays are shown in Table 4. In the group of 31 Roraima-born blood donor candidates, three had $>2$ positive assays (Table 5). Differences for positive IIF were not statistically significant for the different areas ( $\mathrm{p}$ $>0.05)$.

6. Xenodiagnosis: One individual from Maranhão had positive xenodiagnosis (Table 5).

7. PCR: Two individuals presented positive PCR. These settlers were migrants, one from Maranhão (this one also xenodiagnosis positive) and the other from Minas Gerais (Table 5).

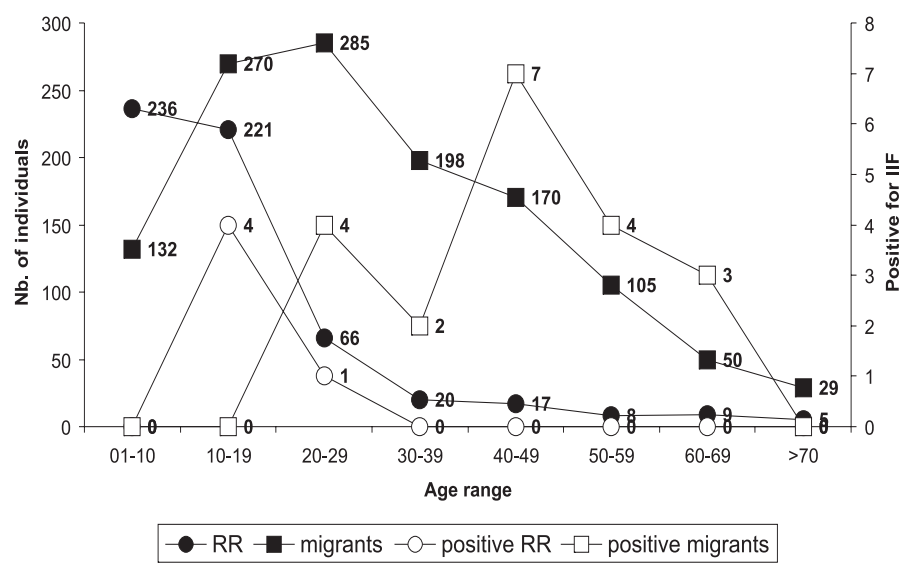

Fig. 3 - Age range according to origin (RR- born in Roraima and migrants) and number of individuals positive for Chagas disease by IIF-indirect immunofluorescence, for settlers living in 3 agricultural settlements in Roraima, Brazil.

\section{DISCUSSION AND CONCLUSION}

Roraima is not considered an endemic area for Chagas disease. However, an intense process of immigration from populations of endemic Chagas disease areas, mainly from the Northern and Northeastern regions of Brazil, has characterized Roraima's process of occupation in the last 20 years. Settlement is carried out on generally poor infrastructure conditions of housing, health and means of sustainability in ecosystems where potential vectors are abundant. These conditions favor the establishment of many diseases like Chagas disease and malaria (SILVA-VASCONCELOS et al., 2002).

All the elements of the T. cruzi transmission cycle are present in the settlement areas. The three agricultural settlements studied, Rorainópolis, Passarão and Ilha present palm-trees sometimes in high density, in contiguity with the domiciliary environment. Buriti palmtrees are a suitable habitat for triatomines. $R$. pictipes and $R$. robustus have been reported in those trees in other regions (GAMBOA, 1963; CARCAVALLO et al., 1975; OTERO et al., 1975; MILES et al., 1983). Settlements also possess animal annexes in close relationship with the human domicile that can be abundant blood source for triatomines and maintain a peridomiciliary $T$. cruzi cycle. Also findings of positive sera for Chagas disease from the Roraima blood bank (F. A. MENEZESDA-SILVA, personal communication) indicate the likelihood of Chagas disease to become endemic in the region.

Triatoma maculata was found in buriti palm trees in the vicinities of agricultural settlement domiciles. The species has been implicated in the transmission in the Guyanas, Venezuela and Colombia, countries neighbouring Roraima, where it has been found naturally infected (DIAS, 1952). T. maculata was found infesting houses in the Venezuelan endemic rural area (TONN et al., 1976; TONN et al., 1978; ZELEDON \& RABINOVITCH, 1981). Also in Venezuela, T. maculata specimens were found naturally infected by $T$. cruzi and T. rangeli (PIFANO, 1973; SIFONTES, 1976).

The presence of triatomines in the close domicile vicinities, such as animal annexes demonstrates the potentiality of domiciliation for the triatomine populations in the region. Triatomine domiciliation is considered one of the major risk factors in the Chagas disease establishment involving humans (DIAS et al., 2002). In fact, the Passarão T. maculata population presents biological characteristics of

Table 4

Positive serology by indirect immunofluorescence for settlers living in three agricultural settlements in Roraima

\begin{tabular}{|c|c|c|c|c|c|c|c|c|c|}
\hline & \multicolumn{3}{|c|}{ Born in Roraima } & \multicolumn{3}{|c|}{ Migrants } & \multicolumn{3}{|c|}{ Total } \\
\hline & Examined & $+\mathrm{IIF}$ & $(\%)$ & Examined & + IIF & $(\%)$ & Examined & $+\mathrm{IIF}$ & $(\%)$ \\
\hline \multicolumn{10}{|l|}{ Settlement } \\
\hline Rorainópolis & 427 & 3 & $(0.7)$ & 1161 & 18 & $(1.6)$ & 1588 & 21 & (1.3) \\
\hline Passarão & 74 & - & (0) & 76 & 2 & $(2.6)$ & 150 & 2 & (1.3) \\
\hline Ilha & 81 & 2 & $(2.5)$ & 2 & - & (0) & 83 & 2 & (2.4) \\
\hline TOTAL & 582 & 5 & $(0.9)$ & 1239 & 20 & $(1.6)$ & 1821 & 25 & $(1.4)$ \\
\hline
\end{tabular}

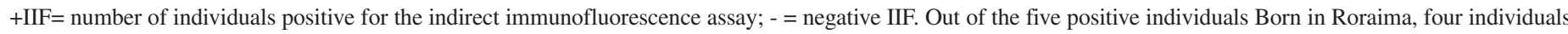

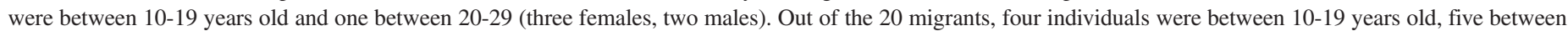
20-29, two between 30-39, seven between 40-49, four between 50-59 and three above 60 years old (10 females, 10 males). 
Table 5

Settlers and blood donor candidates with positive results for at least two assays

\begin{tabular}{|c|c|c|c|c|c|c|c|c|c|c|c|c|c|}
\hline \multirow[t]{2}{*}{ Age } & \multirow[t]{2}{*}{ Sex } & \multirow[t]{2}{*}{ Origin } & \multirow[t]{2}{*}{ Settlement } & \multirow[t]{2}{*}{ Past informed diseases } & \multirow[t]{2}{*}{$+\mathrm{IIF}$} & \multirow[t]{2}{*}{$+\mathrm{IHA}$} & \multicolumn{2}{|c|}{ C-ELISA } & \multicolumn{2}{|c|}{ R-ELISA } & \multirow{2}{*}{$\begin{array}{c}\text { Xeno } \\
\text { diagnosis }\end{array}$} & \multirow[t]{2}{*}{ PCR } & \multirow[t]{2}{*}{ Code } \\
\hline & & & & & & & Result & Value & Result & Value & & & \\
\hline 47 & M & $\begin{array}{l}\text { Minas } \\
\text { Gerais }\end{array}$ & Rorainópolis & $\begin{array}{l}\text { Malaria, tegumentar } \\
\text { leishmaniasis }\end{array}$ & 160 & 320 & + & 0.825 & - & 0.313 & + & + & RR62 \\
\hline 56 & $\mathrm{~F}$ & Maranhão & Rorainópolis & Malaria & 80 & 320 & + & 0.844 & + & 0.268 & - & + & RR28 \\
\hline 63 & $\mathrm{~F}$ & Maranhão & Rorainópolis & $\begin{array}{l}\text { Malaria, tegumentar } \\
\text { leishmaniasis }\end{array}$ & 40 & - & + & 0.264 & - & 0.060 & - & - & RR64 \\
\hline 16 & $\mathrm{~F}$ & Roraima & Ilha & Unknown & 40 & - & + & 0.315 & - & 0.064 & - & - & RR67 \\
\hline 43 & $\mathrm{~F}$ & Maranhão & Rorainópolis & Unknown & 40 & - & + & 0.711 & - & 0.066 & - & - & RR68 \\
\hline 41 & $\mathrm{~F}$ & Maranhão & Rorainópolis & Malaria & 40 & 40 & - & 0.207 & - & 0.079 & - & - & RR13 \\
\hline 27 & M & Maranhão & Rorainópolis & Malaria & 80 & 40 & - & 0.208 & - & 0.046 & - & - & RR27 \\
\hline 44 & $\mathrm{~F}$ & Maranhão & Rorainópolis & Malaria & 40 & 40 & - & 0.196 & - & 0.058 & - & - & RR15 \\
\hline 40 & M & Maranhão & Rorainópolis & Malaria & 40 & - & + & 0.276 & - & 0.059 & - & - & RR58 \\
\hline 18 & M & Roraima & Ilha & Malaria & 40 & - & + & 0.333 & - & 0.057 & - & - & RR46 \\
\hline 20 & M & Pará & Rorainópolis & Malaria & 40 & - & + & 0.291 & - & 0.042 & - & - & RR101 \\
\hline 26 & $\mathrm{~F}$ & Roraima & Rorainópolis & Malaria & 40 & - & + & 0.281 & - & 0.066 & - & - & RR31 \\
\hline 20 & $M$ & Roraima & Hemocentro & Unknown & 40 & - & + & 0.275 & - & 0.051 & - & nd & RR233 \\
\hline 23 & M & Roraima & Hemocentro & Unknown & 40 & - & + & 0.568 & - & 0.050 & - & nd & RR203 \\
\hline 20 & M & Roraima & Hemocentro & Malaria & 40 & - & + & 0.481 & - & 0.044 & - & nd & RR235 \\
\hline
\end{tabular}

Results given as sera title values for IIF-immunofluorescence and IHA- hemmaglutination assays; ELISA-C- conventional ELISA (cut-off value = 0.260), R ELISARecombinant ELISA (cut-off value = 0.202); + positive, - negative, nd = non determined. Sera dilutions were 1:40 for IIF and IHA, 1:100 for ELISA, 50 $\mu$ l of non-diluted sera for R ELISA.

a suitable vector (among others exhibits a low elapsed time for defecation after a blood meal, LUITGARDS-MOURA et al. in preparation).

Notwithstanding the low percentage of infected humans found (two individuals out of the 1588 investigated or $0.13 \%$, one with circulating trypomastigotes), the risk of vectorial and transfusional transmission is clearly present.

The estimation of the prevalence of $T$. cruzi in humans in a given area can become a difficult task. There are problems related to falsenegatives and false-positives. Many false-negative result from parasite visualization based approaches where only 20 to $50 \%$ of the infected individuals are detected (GOMES, 1997). False-positives result from cross-reaction in antibody detection-based techniques like IIF, IHA and ELISA (with leishmaniasis, CAMARGO \& HOSHINO SHIMIZU, 1974 and, hanseniasis, tuberculosis and T. rangeli TOZETTI, 1997; COURA et al., 1999). IHA, due to its easy handling and quick results, has been frequently used in the selection of blood-donors (TEIXEIRA, 1994), even though rigorous standards are required for IHA reliability (CAMARGO et al., 1987). ELISA has been used to corroborate serodiagnosis in blood banks and in clinical-epidemiological studies but technique improvement has been a constant concern (ZAUZA, 2000). To complicate, the accuracy of diagnostic techniques nonetheless varies for different endemic regions possibly due to genetic profiles peculiarities of $T$. cruzi populations circulating in each area (COURA et al., 1994c). Inconclusive serology, i.e., reactivity is in the threshold for two or more techniques may be attributed to purification (STOLF, 1992). Notwithstanding the fact that accuracy was improved due to the use of 2-mercaptoethanol IHA and recombinant ELISA, the percentage of inconclusive sera in the studied individuals reached $30 \%$ (using IIF or ELISA, but not using recombinant ELISA).

IIF positive sera found were $0.8 \%$ among Roraima born individuals and $1.6 \%$ among migrants. NSI values were $0.3 \%$ value for Boa Vista and Caracaraí (CAMARGO et al., 1984). Even though the sampling methods for both inquiries cannot be compared, the values found show that some human groupings may present higher values. COURA et al. (1995a) found $12.5 \%$ IIF positive sera in Barcelos, Amazon State, a population located $60 \mathrm{~km}$ far from Rorainópolis. This was a 6-times increase in positivity compared to the NSI. On the other hand, in Minas Gerais, Goiás and Piauí States, where estimates of prevalence of Chagas infection were above $4 \%$ of the population (NSI, CAMARGO et al., 1984), punctual studies in Mambaí (Goiás State, CASTRO et al., 1987), Oieras (Piauí State, ALVES-FILHO, 1995) and Virgem da Lapa (Minas Gerais State, BORGES-PEREIRA, 1997), showed percentages not exceeding 2-times the $4 \%$ estimated prevalences. Overall, these findings would point out for the expected trend in Chagas disease cases increase in the Amazon.

Among 15 seropositives only two migrants were positive for all assays (including PCR and one with positive xenodiagnosis, Table 5). They had anti-T.cruzi antibody levels above the remaining seropositive individuals (Table 5). Interestingly, all (except one) positive sera were negative for recombinant ELISA, considered to have high specificity for T.cruzi (KRIEGER et al., 1992; CARVALHO, 1992; GOMES et al., 2001).

Two migrant settlers are undoubtedly positive, one from Minas Gerais and the other from Maranhão, states in the endemic Chagas 


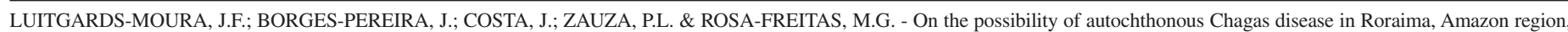
Brazil, 2000-2001. Rev. Inst. Med. trop. S. Paulo, 47(1):45-54, 2005.

disease zone (Table 5). Both patients were referred to the Roraima General Hospital-HGR for follow-up. The Maranhão settler is a 56 years old female. The Minas Gerais settler, a 47 years old male, was also xenodiagnosis positive, i.e., had infective trypomastigote forms circulating in his blood. These individuals live in Rorainópolis an area with high peridomiciliary triatomine infestation index. Individuals with these characteristics may be more frequent than unveiled in the present study and may play an important role in Chagas disease implantation.

\section{CONCLUSIONS}

Chagas disease is not currently endemic in Roraima, as indicate by the lack of infected Roraima born individuals, domiciliated triatomines and natural infection in both human vertebrate and invertebrate hosts.

The active migration of individuals from Chagas disease endemic regions, the presence of infected humans, potential vectors in high densities in the peridomicile, suitable house conditions for triatomine domiciliation are all risk factors that point out to the possibility of Trypanosoma cruzi to establish an autochthonous cycle involving humans in Roraima. A continuous epidemiological vigilance involving active engagement of settlers in the recognition of vectors and the disease, permanent entomological surveys, determination of T. cruzi circulating strains and increased awareness through educational campaigns for the public, settlers and health agents for the possibility of Chagas disease cases in Roraima is advisable.

\section{RESUMO}

\section{Sobre a possibilidade da ocorrência de doença de Chagas autóctone em Roraima, Amazônia brasileira, 2000-2001}

A doença de Chagas foi quase inteiramente erradicada das zonas áridas do Brasil Central e Nordeste, onde ciclos autóctones de transmissão praticamente inexistem. Contudo, na última década a doença vem sendo registrada na Região Amazônica. Objetivando investigar a possibilidade da ocorrência de ciclos autóctones de transmissão em áreas de colonização agrícola no Estado de Roraima, foram realizadas coletas de triatomíneos e estudos de sua biologia (a ser mostrado em outro artigo), sorologia (imunofluorescência, hemaglutinação, ELISA) e pesquisa parasitológica (xenodiagnóstico, PCR) entre moradores de Rorainópolis, do Projeto Passarão e da Comunidade da Ilha. Candidatos a doação sanguínea do Hemocentro de Boa Vista também foram avaliados. Foram coletados Triatoma maculata, Rhodnius pictipes, Rhodnius robustus e Panstrongylus geniculatus em palmeiras-buriti Mauritia flexuosa, em anexos peridomiciliares e em domicílios. Nenhum triatomíneo foi encontrado naturalmente infectado. A presença de anticorpos anti-Trypanosoma cruzi foi verificada em 25 indivíduos (1,4\% de um total de 1821), 20 dos quais migrantes, todos adultos $>15$ anos. Apenas dois indivíduos migrantes tiveram mais de dois exames sorológicos positivos (um ainda com xenodiagnóstico positivo e o outro com PCR positivo), estando seguramente infectados. Os resultados mostram que apesar de não ser endêmica, há a presença de todos os elos da cadeia de transmissão da doença de Chagas em Roraima que permitem a sua instalação na ausência de vigilância.

\section{ACKNOWLEDGEMENTS}

To Constança Britto for PCR advisory, Hemocentro de Roraima, Fundação Nacional de Saúde-FUNASA, Laboratório Central-LACEN, Instituto Brasileiro de Geografia e Estatística - IBGE-Roraima, Secretaria do Estado de Saúde de Roraima-SESAU, Secretaria Municipal de Saúde-SEMSA, Prefeitura de Boa Vista for data availability and two anonymous referees for their invaluable contributions.

This study is part of the PhD thesis of José Francisco LuitgardsMoura. The work was supported by CNPq-Brazil (Brazilian Council for Science and Technology, 521176/ 98-0), the Oswaldo Cruz Institute/ FIOCRUZ and the Roraima Federal University/UFRR.

\section{REFERENCES}

1. ALVES FILHO, F.I. - Morbidade da doença de Chagas em áreas endêmicas dos municípios de Oeiras e Colônia do Piauí. Rio de Janeiro, 1995. (Dissertação de mestrado - Instituto Oswaldo Cruz).

2. AVILA, H.; GONCALVES, A.M.; NEHME, N.S.; MOREL, C.M. \& SIMPSON, L. Schizodeme analysis of Trypanosoma cruzi stocks from South and Central America by analysis of PCR-amplified minicircle variable region sequences. Molec. Biochem. Parasit., 42: 175-187, 1990.

3. BORGES-PEREIRA, J. - Doença de Chagas humana: estudo da infecção crônica, morbidade e mortalidade em Virgem da Lapa, MG, Brasil (1976-1996). Rio de Janeiro, 1997. (Tese de Doutorado - Instituto Oswaldo Cruz).

4. BRITTO, C.; CARDOSO, M.A.; RAVEL, C. et al. - Trypanosoma cruzi: parasite detection and strain discrimination in chronic chagasic patients from northeastern Brazil using PCR amplification of kinetoplast DNA and nonradioative hybridization. Exp. Parasit., 81: 462-471, 1995.

5. CAMARGO, M.E. \& HOSHINO-SHIMIZU, S. - Metodologia sorológica na infecção pelo Trypanosoma cruzi. Rev. goiana Med., 20: 47-65, 1974.

6. CAMARGO, M.E.; SEGURA E.L.; KAGAN I.G. et al. - Normalización del diagnóstico serológico de la enfermedad de Chagas en las Américas: evaluación de tres años de colaboración. Bol. Ofic. sanit. panamer., 102: 449-462, 1987.

7. CAMARGO, M.E.; SILVA G.R.; CASTILHO, E.A. \& SILVEIRA, A.C. - Inquérito sorológico da prevalência chagásica no Brasil, 1975/1980. Rev. Inst. Med. trop. S. Paulo, 26: 192-204, 1984.

8. CARCAVALLO, R.U.; MARTINEZ-SILVA, R.; OTERO, M. \& TONN, R. - Infección natural de Rhodnius robustus Larrousse y Rhodnius pictipes Stål por T. cruzi y $T$. rangeli en Venezuela. Bol. Direcc. Malar., 15: 117-120, 1975.

9. CARVALHO, M.R.C. - Doença de Chagas: utilização de antígenos recombinantes de Trypanosoma cruzi no diagnóstico sorológico e avaliação do comportamento de reagentes imunoenzimáticos frente a sera inconclusivos para os testes sorológicos convencionais. São Paulo, 1992. (Dissertação de mestrado - Instituto de Ciências Biológicas da Universidade de São Paulo).

10. CASTRO, C.N.; REZENDE, J.M.; CAMARGO, M.; PRATA, A. \& MACEDO, V. Prevalência da esofagopatia chagásica no município de Mambaí, Goiás, Brasil. Rev. Soc. bras. Med. trop., 20: 13-17, 1987.

11. CERISOLA, J.A.; ALVAREZ, M.; BOCK, M. \& WEGNER, D. - A comparison of a new antigen from amastigotes of Trypanosoma cruzi and an antigen from epimastigotes for the diagnosis of Chagas disease by the indirect immunofluorescence test. Rev. Inst. Med. trop. S. Paulo, 13: 162-166, 1971. 
12. COURA, J.R.; ARBOLEDA-NARANJO, M. \& WILLCOX, H.P.F. - Chagas disease in the Brazilian Amazon. II. A serological survey. Rev. Inst. Med. trop. S. Paulo, 37: 103-107, 1995a.

13. COURA, J.R.; BARRETT, T.V. \& ARBOLEDA-NARANJO, M. - Ataque de populações humanas por triatomíneos silvestres no Amazonas: uma nova forma de transmissão da infecção chagásica? Rev. Soc. bras. Med. trop., 27: 251-253, 1994a.

14. COURA, J.R.; JUNQUEIRA, A.C.V.; BOIA, M.N. \& FERNANDES, O. - Chagas disease: from bush to huts and houses. Is it the case of the Brazilian Amazon? Mem. Inst. Oswaldo Cruz, 94(suppl. 1): 379-384, 1999

15. COURA, J.R.; JUNQUEIRA, A.C.V.; GIORDANO, C.M. \& FUNATSU, R.K. - Chagas disease in the Brazilian Amazon. I. A short review. Rev. Inst. Med. trop. S. Paulo, 36: 363-368, 1994b.

16. COURA, J.R.; WILLCOX, H.P.F.; ARBOLEDA-NARANJO, M.; FERNANDES, O. \& PAIVA, D.D. - Chagas disease in the Brazilian Amazon. III. A cross-sectional study. Rev. Inst. Med. trop. S. Paulo, 37: 415-420, 1995b.

17. COURA, J.R.; WILLCOX, H.P.F.; TAVARES, A.M. et al. - Aspectos epidemiológicos, sociais e sanitários de uma área no Rio Negro, estado do Amazonas, com especial referência às parasitoses intestinais e à infecção chagásica. Cadern. Saude públ., 10 (supl. 2): 327-336, 1994c.

18. DIAS, E. - Doença de Chagas nas Américas. IV. Colômbia, Venezuela e Guianas. Rev. bras. Malar., 4: 255-280, 1952.

19. DIAS, J.C.P.; PRATA, A. \& SCHOFIELD, C.J. - Doença de Chagas na Amazônia: esboço da situação atual e perspectivas de prevenção. Rev. Soc. bras. Med. trop., 35: 669678, 2002.

20. FRAIHA-NETO, H.; VALENTE, S.A.S.; VALENTE, V.C. \& PINTO, A.Y.N. - Doença de Chagas-endêmica na Amazônia? An. Acad. Med. Pará, 6: 53-57, 1995.

21. FREITAS, A. - Geografia e Historia de Roraima. Manaus, Editora Grafima, 1996.

22. FUNASA/Fundação Nacional de Saúde - Guia de Vigilância Epidemiológica. Brasília, Ministério da Saúde/Fundação Nacional da Saúde, 2002. v. 1.

23. GAMBOA, C.J. - Comprobácion de Rhodnius prolixus extradomiciliario en Venezuela. Bol. Ofic. sanit. panamer., 59: 18-25, 1963.

24. GOMES, Y.M. - PCR and sero-diagnosis in chronic Chagas' disease. Biotechnological advances. Appl. Biochem. Biotech., 66: 107-119, 1997

25. GOMES, Y.M.; PEREIRA, V.R.A.; NAKAZAWA, M. et al. - Serodiagnosis of chronic Chagas infection by using EIE-recombinant-Chagas-Biomanguinhos Kit. Mem. Inst. Oswaldo Cruz, 96: 497-501, 2001.

26. IBGE/Instituto Brasileiro de Geografia e Estatística 2000. Censo 2000, População. Sinopse preliminar. http://www.ibge.gov.br

27. JUNQUEIRA, A.C.V.; CHIARI, E. \& WINCKER, P. - Comparison of the polymerase chain reaction with two classical parasitological methods for the diagnosis of Chagas disease in an endemic region of north-eastern Brazil. Trans. roy. Soc. trop. Med. Hyg., 90: 129-132, 1996.

28. KRIEGER, M.A.; ALMEIDA, E.; OELEMANN, W. et al. - Use of recombinant antigens for the accurate immunodiagnosis of Chagas' disease. Amer. J. trop. Med. Hyg., 46: 427-434, 1992

29. LENT, H. \& WYGODZINSKY, P. - Revision of the triatominae (Hemiptera, Reduviidae), and their significance as vector of Chagas disease. Bull. Amer. Mus. Nat. Hist., 163: 125-520, 1979.

30. LUITGARDS-MOURA, J.F. - Aspectos epidemiológicos da doença de Chagas em áreas de colonizaçao agrícola no estado de Roraima, Brasil. Rio de Janeiro, 2001. (Tese de Doutorado - Instituto Oswaldo Cruz).
31. MILES, M.A.; ARIAS, J.R. \& SOUZA, A.A. - Chagas' disease in the Amazon Basin. V. Periurban palms as habitats of Rhodnius robustus and Rhodnius pictipes - Triatominae vectors of Chagas' disease. Mem. Inst. Oswaldo Cruz, 78: 391-398, 1983.

32. MINISTÉRIO DAS MINAS E ENERGIA. Projeto RADAMBRASIL - Roraima: geomorfologia, pedologia, vegetação e uso potencial da terra. Rio de Janeiro, 1975.

33. NATIONAL Aeronautics and Space Administration NASA 2000. http:// eosweb. larc. nasa. gov/ sse/

34. OTERO, M.A.; JIMENEZ, J.C.; CARCAVALLO, R.U.; ORTEGA, R. \& TONN, R.J. Actualización de la distribución geográfica de Triatominae (Hemiptera, Reduviidae) en Venezuela. Bol. Direcc. Malar., 15: 217-230, 1975.

35. PIFANO, C.F.R. - La dinámica epidemiológica de la Enfermedad de Chagas en el Valle de los Naranjos, estado de Carabobo, Venezuela. Arch. venez. Med. trop. Parasit. Med., 5: 31-45, 1973.

36. PROGRAMS and policies of the Pan American Health Organization. Bull. Pan. Amer. Hlth. Org., 10: 189-192, 1976

37. ROSA-FREITAS, M.G.; TSOURIS P.A.; SIBAJEV, A. et al. - Exploratory temporal and spatial distribution analysis of dengue notifications in Boa Vista, Roraima, Brazilian Amazon, 1999 to 2001. Dengue Bull., 27: 63-80, 2003.

38. SAIKI, R.K.; SCHARF, S.; FALOONA, F. et al. - Enzymatic amplification of beta-globin genomic sequences and restriction site analysis for diagnosis of sickle cell anemia. Science, 230: 1350-1354, 1985.

39. SHAW, J.; LAINSON, R. \& FRAHIA, H. Considerações sobre a epidemiologia dos primeiros casos autóctones de doença de Chagas registrados em Belém, Pará, Brasil. Rev. Saúde públ. (S. Paulo), 3: 153-157, 1969.

40. SIFONTES, R. - Desarollo y estado actual del programa de control de la enfermedad de Chagas en Venezuela. In: Congresso Latinoamericano de Parasitología, 4., San José, Costa Rica, 1976.

41. SILVA-VASCONCELOS, A.S.; KATO, M.Y.N.; MOURÃO, E.N. et al. - Biting indices, host-seeking activity and natural infection of anopheline species in Boa Vista, Roraima, Brazil from 1996 to 1998. Mem. Inst. Oswaldo Cruz, 97: 151-161, 2002.

42. SOUZA, S.L. \& CAMARGO, M.E. - The use of filter paper blood smear in a practical fluorescent test for American Trypanosomiasis serodiagnosis. Rev. Inst. Med. trop. S. Paulo, 8: 255-258, 1966.

43. STOLF, M.A.S. - Trypanosoma cruzi antigens in serodiagnosis. In: WENDEL, S.; BRENER, Z.; CAMARGO, M.E. \& RASSI, A. Chagas' disease American trypanosomiasis: its impact on transfusion and clinical medicine. São Paulo, ISBT, 1992. p. $195-205$

44. STURM, N.R.; DEGRAVE, W.; MOREL, C. \& SIMPSON, L. - Sensitive detection and schizodeme classification of Trypanosoma cruzi cells by amplification of kinetoplast minicircle DNA sequences: use in diagnosis of Chagas disease. Molec. Biochem. Parasit. 33: 205-214, 1989.

45. TEIXEIRA, M.G.M. - Avaliação de testes sorológicos e desenvolvimento de ensaios imunoenzimáticos, com alta especificidade, para o diagnóstico da doença de Chagas. Rio de Janeiro, 1994. (Dissertação de Mestrado - Instituto Oswaldo Cruz).

46. TONN, R.J.; CARCAVAllO, R.U.; ORTEGA, R. \& CARRASQUERO, B. - Métodos de estudio de triatóminos en el médio silvestre. Bol. Direcc. Malar., 16: 146-152, 1976

47. TONN, R.J.; OTERO, M.A.; MORA, R.; ESPINOLA, H. \& CARCAVALLO, R.U. Aspectos biológicos, ecológicos y distribución geográfica de Triatoma maculata (Erichson, 1848) en Venezuela. Bol. Direcc. Malar., 18: 16-24, 1978. 


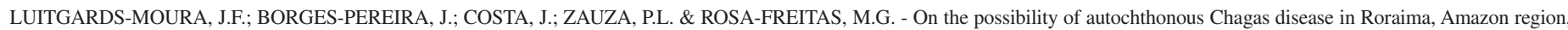
Brazil, 2000-2001. Rev. Inst. Med. trop. S. Paulo, 47(1):45-54, 2005.

48. TOZETTI, J.A. - Avaliação de diferentes extratos antigênicos de Trypanosoma cruzi provenientes de cepas da América Latina por imunofluorescência indireta (IFI), ELISA, eletroforese em gel de poliacrilamida (DSD-PAGE) e western blotting. Influência da diversidade antigênica sobre os resultados dos testes sorológicos. São Paulo, 1997. (Dissertação de Mestrado - Instituto de Ciências Biológicas da Universidade de São Paulo).

49. VALENTE, S.A.S.; VALENTE, V.C. \& FRAHIA-NETO, H. - Considerations on the epidemiology and transmission of Chagas' disease in the Brazilian Amazon. Mem. Inst. Oswaldo Cruz, 94 (suppl.1): 395-398, 1999.

50. VALENTE, V.C.; VALENTE, S.A.S.; NOIREAU, F.; CARRASCO, H.J. \& MILES, M.A. - Chagas disease in the Amazon Basin: association of Panstrongylus geniculatus (Hemiptera: Reduviidae) with domestic pigs. J. med. Entomol., 35: 99-103, 1998.
51. WINCKER, P.; BRITTO, C.; BORGES-PEREIRA, J. et al. - Use of a simplified polymerase chain reaction procedure to detect Trypanosoma cruzi in blood samples from chronic chagasic patients in a rural endemic area. Amer. J. trop. Med. Hyg., 51: 771-777, 1994.

52. ZAUZA, P.L. - Avaliação dos níveis de anticorpos (IgG) anti-T. cruzi em sera de pacientes chagásicos crônicos de Virgem da Lapa, Minas Gerais, Brasil. Rio de Janeiro, 2000. (Dissertação de Mestrado - Instituto Oswaldo Cruz).

53. ZELEDÓN, R. \& RABINOVICH, J.E. - Chagas` disease: an ecological appraisal with special emphasis on its insect vectors. Ann. Rev. Entomol., 26: 101-133. 1981.

Received: 8 July 2004

Accepted: 11 November 2004 